\title{
A new early brachyuran (Crustacea, Decapoda) from the Middle Jurassic of northwest France, epibionts and ecological considerations
}

\author{
Ninon Robin ${ }^{1,4}$, Barry W.M. van Bakel ${ }^{2}$, Jean-Loup d'Hondt ${ }^{3}$, Sylvain Charbonnier ${ }^{1}$ \\ ${ }^{1}$ Muséum national d'histoire naturelle, Centre de Recherches sur la Paléobiodiversité et les Paléoenvironnements \\ (CR2P, UMR 7207), Sorbonne Universités-MNHN, CNRS, UPMC-Paris6, 8 rue Buffon, F-75005, Paris, France \\ ${ }^{2}$ Oertijdmuseum De Groene Poort, Bosscheweg 80, 5283 WB Boxtel, The Netherlands; and Naturalis Biodiversity \\ Center, P.O. Box 9517, NL-2300 RA Leiden, The Netherlands \\ ${ }^{3}$ Muséum national d'Histoire naturelle, case postale 39, 57 rue Cuvier, F-75005, Paris, France \\ ${ }^{4}$ E-mail: ninon.robin@edu.mnhn.fr
}

Key words: Bathonian, cyclostome bryozoans, epibiosis, episkeletozoans, Homolodromioidea

\begin{abstract}
The earliest known crabs are of Early and Middle Jurassic age; in general, they are rare. Here we describe a new species of homolodromioid from the late Bathonian of Sarthe (France), based on a single dorsal carapace, Tanidromites raboeufi $\mathrm{n}$. sp. This specimen has mostly well-preserved cuticle, and shows two episkeletozoans (bryozoan colonies) on its dorsal side, which is unique amongst early brachyurans (Early and Middle Jurassic). These bryozoans are identified as juvenile colonies of the morphogenus Berenicea (sheet-like tubuluporines), typical encrusters of hard substrates. Their presence directly on the carapace crab shows that they were closely cohabitating with this early brachyuran in its palaeoenvironment. One of these colonies appears to have attached to the internal carapace surface, indicative of post-mortem settlement and growth. Colony sizes suggest a growth phase of at least several months on the sea floor, implying a certain resistance to decomposition of the crab carapace. This is of note in the light of extant homolodromioids which are known to have extremely fragile carapaces. This association demonstrates that post-mortem associations may yield palaeoecological insights into both substrate and colonising organisms.
\end{abstract}

\section{Contents}

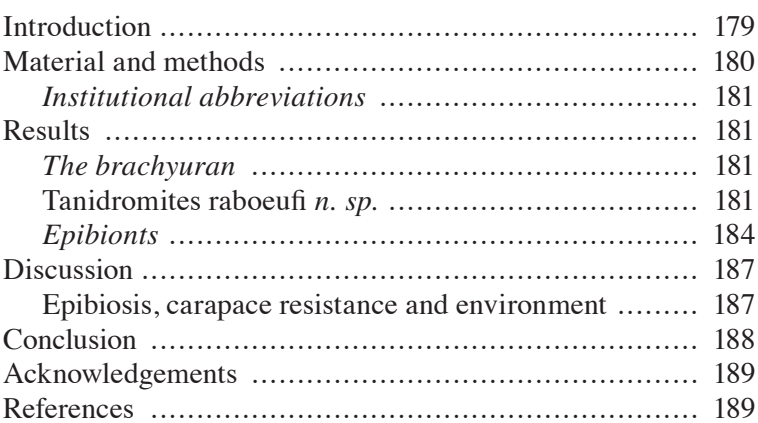

\section{Introduction}

Epibiosis and epibionts have been defined in numerous ways (West, 1977; Wahl, 1989; Walker and Miller, 1992), focusing either on the organic nature of the coloniser or on that of the colonised substrate. There is a difference of opinion as far as the live condition of the host organism is concerned: compulsory to some authors (Wahl, 1989), not to others (Walker and Miller 1992; Gutt and Shickan, 1998). Our study aims to define the nature of the fossil association observed, and we prefer the use of the terms epibiosis/epibionts because they do not depend on the live/dead condition of the substrate. We here adopt the terminology proposed by Taylor and Wilson (2002) to specify its syn-vivo or post-mortem nature, by using the terms epizoozoans or episkeletozoans respectively. We also use 'symbiosis' in its original, broad definition (de Bary, 1879), i.e. the direct (either brief or long-lasting) association of two living organisms. This definition permits consideration of the widest diversity of associations without regard to the effect, permanency or interdependence of the partner species, which cannot be easily extracted based on fossil associations. This is the most useful definition to study fossil interspecific associations.

As argued by some authors, the paucity of fossil evidence for symbiosis on decapod crustaceans can be attributed to several factors, i.e. extrinsic ones, such as the soft (non-durable) composition of most of their modern epizoans (anthozoans, ascidians, bacteria), which do not leave any trace of their presence after their removal and thus have no fossil record (Feldmann, 2003), and intrinsic others such as moulting or grooming habits, repelling any sustainable settlement (Waugh et al., 2004). 
Among extant decapod crustaceans, symbiotic bryozoans are frequently recorded in brachyurans (Ryland and Stebbing, 1971; Mori and Manconi, 1990; Cadée, 1991; Becker and Wahl, 1996; Abello and Corbera, 1996; Parapar et al., 1997; Key et al., 1999; Gordon and Wear, 1999; Fernandez-Leborans, 2003; Waugh et al., 2004; McGaw, 2006; Savoie et al., 2007; McDermott, 2007) and in anomurans (Buge and Lecointre, 1962; Schembri, 1982; Walker, 1988; Taylor et al., 1989; Taylor, 1994; McDermott, 2001; Carter and Gordon, 2007, Klicpera et al., 2013).

To date, the oldest confirmed brachyuran is of Pliensbachian (Early Jurassic) age (Förster, 1986); it belongs to the Homolodromioidea Alcock, 1900 (Förster, 1986; Schweitzer and Feldmann, 2010a; Haug and Haug, 2014). A new representative of this superfamily, Tanidromites raboeufi $\mathrm{n}$. sp., is here recorded from the upper Bathonian (Middle Jurassic) of Crannes-en-Champagne (Sarthe, France). This specimen, with a mostly wellpreserved cuticle, shows two episkeletozoans (bryozoan colonies) on its dorsal side, which is unique amongst the earliest brachyurans (Early and Middle Jurassic). Indeed, epibiotic forms were reported on brachyurans from the Late Jurassic of Europe (Oxfordian, Feldmann et al., 2006; Tithonian, Schweitzer and Feldmann, 2009), but never on so old crabs. The true nature of this association (syn-vivo versus post-mortem) is here consid- ered; it provides new palaeoecological insights into the rare early brachyurans (in this case, $c a 167$ myr old), and some of their sympatric organisms. The scarcity of epizoans on fossil decapod crustaceans and their few studies make the present bryozoans worthy of detailed consideration.

\section{Material and methods}

The specimen studied here is housed in the palaeontological collections of the Musée Vert-Muséum d'Histoire naturelle du Mans (Sarthe, France), bearing registration number MHNLM 2013.2.1. It was collected in 2013 by Patrick Raboeuf at La Bigotière, near the village of Crannes-en-Champagne, Sarthe department, Pays-de-la-Loire region, France (Fig. 1). The specimen originates from the Calcaire à Montlivaultia sarthacensis Formation, which is dated by ammonites as late Bathonian (Retrocostatum Biozone) (Guillier and Chelot, 1886). This formation, 3 to 4 metres thick, is composed of poorly stratified limestone beds, which yield abundant fossils, such as ammonites, gastropods, bivalves, brachiopods, bryozoans, echinoids, corals and sponges (Guiller and Chelot, 1886; Clément et al., 1987). The studied specimen seems to be the first report of a decapod crustacean from this unit. Palaeogeographical

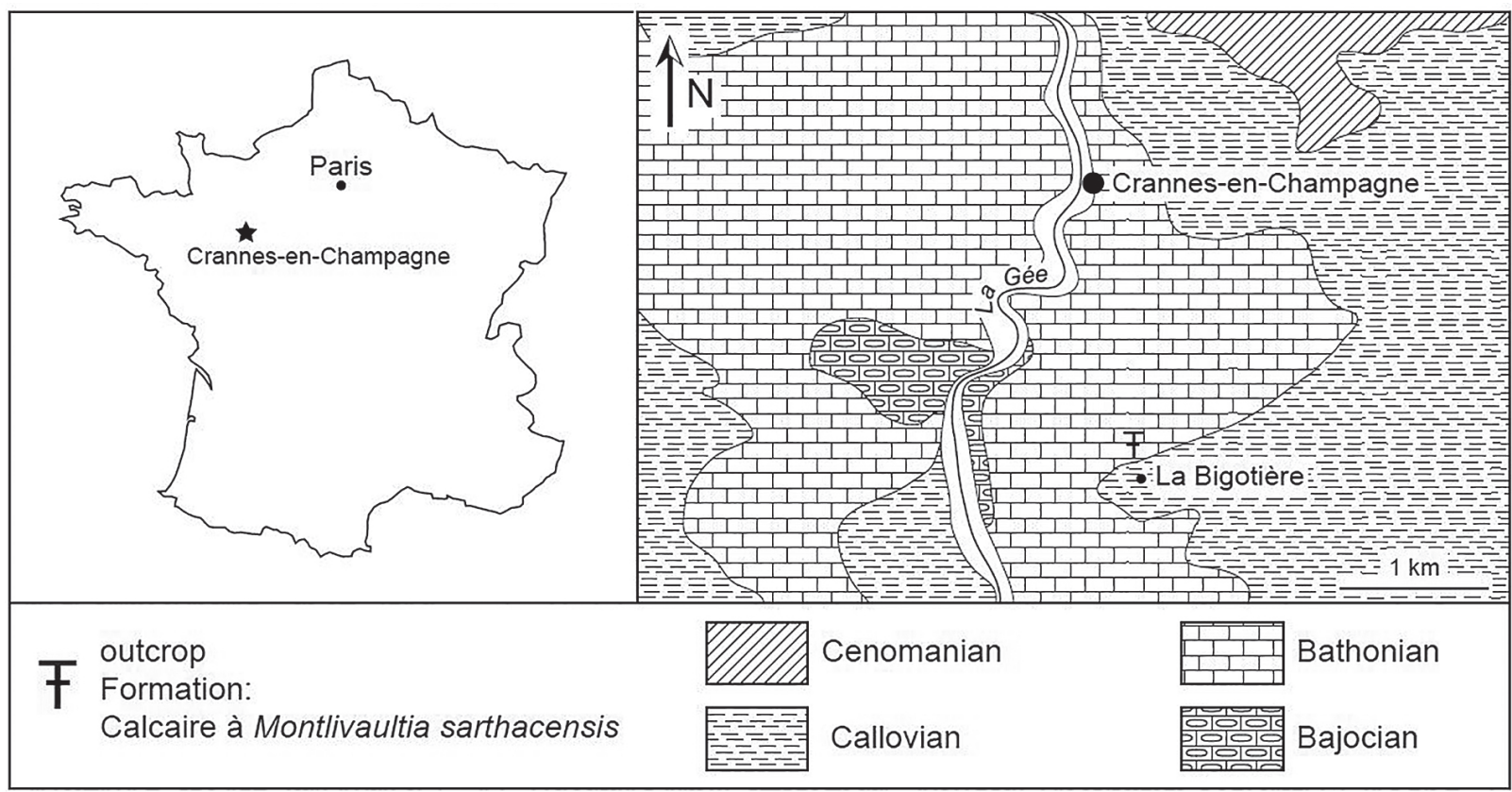

Fig. 1. Geographical and geological setting of the outcrop that yielded specimen MHNLM 2013.2.1 (geological map simplified after Clément et al., 1987). 
reconstructions for the Middle Jurassic place the Crannes-en-Champagne area along the western margin of the Paris Basin and adjacent to the Armorican Massif which was probably not completely submerged at that time (Mégnien, 1980; Enay et al., 1993). It was part of a shallow carbonate platform (Clément et al., 1987).

A second brachyuran specimen is here figured for its equivalent epibiotic pattern of bryozoan colonies. Bearing registration number MNHB-MB.A19171, the specimen is identified as Dromiopsis rugosa (von Schlotheim, 1820) from the Danian of Fakse (Denmark). It is housed at the Museum für Naturkunde, Humboldt University of Berlin (Germany).

Epibionts were observed in situ using a Tescan SEM (VEGA II LSU) at the Direction des Collections (MNHN, Paris), linked to an X-ray detector of type SD3 (Bruker). The systematics used in the present paper follow that used in papers on Late Jurassic cyclostomatous bryozoans (see Taylor, 2009; Zaton et al., 2013) and that of Guinot et al. (2013) for the brachyurans.

\section{Institutional abbreviations}

FSL, Université Claude Bernard Lyon 1 (France); MAB, Oertijdmuseum De Groene Poort, Boxtel (The Netherlands); MNHB, Museum für Naturkunde, Humboldt University, Berlin (Germany); MNHN.F, Collection de Paléontologie, Muséum national d'Histoire naturelle, Paris (France); MHNLM, Musée Vert-Muséum d'Histoire naturelle du Mans, Sarthe (France).

\section{Results}

\section{The brachyuran}

Order DECAPODA Latreille, 1802

Infraorder BRACHYURA Latreille, 1802

Section PODOTREMATA Guinot, 1977

Subsection DYNOMENIFORMIA Guinot, Tavares and Castro, 2013

Superfamily HOMOLODROMIOIDEA Alcock, 1900 Family TANIDROMITIDAE Schweitzer and Feldmann, 2008

Genus Tanidromites Schweitzer and Feldmann, 2008

Type species. Prosopon insigne von Meyer, 1860, by original designation.

Included species. Tanidromites etalloni (Collins in Collins and Wierzbowski, 1985) [as Coelopus]; T. insigne (von Meyer, 1860) [as Prosopon]; T. lithuanicus
Schweigert \& Koppka, 2011; T. maerteni Fraaije, Van Bakel, Guinot \& Jagt, 2013; T. montreuilense Crônier \& Boursicot, 2009; T. pustulosa (von Meyer, 1860) [as Prosopon]; T. raboeufi n. sp.; T. richardsoni (Woodward, 1907) [as Prosopon]; T. scheffnerae Schweigert \& Koppka, 2011; T. sculpta (Quenstedt, 1857) [as Prosopon] (= P. elongatum von Meyer, 1857; P. lingulatum von Meyer, 1860).

Remarks. To describe certain carapace features, such as 'anterior groove', 'hepatic pit' and 'hepatic tubercle', we follow Starzyk (2013; fig. 2); to characterise cuticle microstructure, we follow Waugh et al. (2009).

The date of von Meyer's species has been recorded incorrectly on numerous occasions. The type species, Prosopon insigne, was not mentioned by von Meyer $(1857 ; 556)$, although this date appears in virtually all recent publications (Schweitzer and Feldmann, 2008; Crônier and Boursicot, 2009; Hyžný et al., 2011; Schweigert and Koppka, 2011; Fraaije et al., 2013; Starzyk, 2013), even if Glaessner (1929; 321) mentioned the right date of 1860 for Prosopon insigne. Besides, von Meyer $(1858 ; 61)$ proposed the binomen Prosopon insigne but no diagnosis, description or illustrations are supplied, making it a nomen nudum (ICZN art. 12.1). The name did not become available until it appeared in print in his 1860 work, where a description is given (von Meyer, 1860; p. 193). The same holds true for Proposon lingulatum only mentioned in the 1858 paper and accurately published in 1860 (see von Meyer 1860; 205).

Tanidromites raboeufi $n . s p$.

Locality and age. La Bigotière, Crannes-en-Champagne, Sarthe, France; late Bathonian, Retrocostatum Biozone.

Material. Holotype, and sole specimen known, is MHNLM 2013.2.1, a carapace lacking the posterior margin, but with partial preservation of the cuticle; MAB k.3552 represents a cast of this specimen.

Etymology. The specific epithet honors Mr Patrick Raboeuf, who collected and donated the holotype.

Diagnosis. Tanidromites with long anterior carapace portion, outer orbital area rounded, front anteriorly with pseudorostral nodes, rostral margin straight to weakly concave, orbital margin distinctly oblique, epigastric lobes very weak or obsolete, anterior groove absent, mesogastric region weakly defined, cardiac region with two low nodes, post-cervical groove absent, cuticle microstructure with pits.

Description. Carapace of rather large size for genus 
(maximum preserved length $20.2 \mathrm{~mm}$, width 13.5 $\mathrm{mm}$ ), distinctly convex in longitudinal and transverse directions, longer than wide, with subparallel margins, may converge slightly posteriorly (Fig. 2A). Margins gently rounded, except anterior of cervical groove where several granules are lined, anteriormost two granules enlarged, outer orbital spine lacking. Rostrum long, sulcate but sulcus not reaching tip, subtriangular, with pseudorostral nodes (Fig. 2C, arrows), resulting in a blunt tip of rostrum. Orbitofrontal margin continuous, straight to weakly concave, not interrupted by rostro-frontal groove, overall having steep angle, without rim (Fig. 2A, C). Orbits weakly defined, very shallow, with rounded outer orbital fossa (Fig. 2B-C).

Epigastric regions obsolete; mesogastric region weakly defined, except anteriorly at the mesogastric process, base appearing broad, triangular; hepatic regions undefined. Cervical pits circular; hepatic pits or tubercles not observed. Cardiac region weakly vaulted, subpentagonal, with two low nodes lined horizontally. Cervical groove entire, sinuous, widely arched medially where it is relatively shallow, deeper laterally (Fig. 2C). Branchiocardiac groove only clearly defined at outer third, subparallel to cervical groove, shallow, as a weakly curved line.
Cuticle partially preserved, very thin, dorsal cuticle microstructure below cervical groove with widely separated setal pits, more densely packed pits anteriorly and just posterior to cervical groove; orbital and subhepatic areas smooth (Fig. 2B-C). Inner mould, where cuticle lacks, smooth. Abdomen, appendages and ventral side not preserved.

Remarks. The specimen is attributed to Tanidromites on the basis of the elongate carapace outline with parallel margins, a groove pattern with subparallel cervical and branchiocardiac grooves which extend onto the lateral flanks, the triangular shape of the front and weak development of orbits, and the weak development of the lateral margins. It matches the generic diagnosis given by Schweitzer and Feldmann (2008). The genus is well known from the Middle and Upper Jurassic across Europe; the new species does not extend either its geographical or stratigraphical range (see Starzyk, 2013, for further references). The specimen studied does not show any hepatic pit or tubercle; these characters may differ amongst specimens with or without cuticle preserved, and caution must be taken when comparing these features (for further discussion, see Klompmaker et al. 2015).

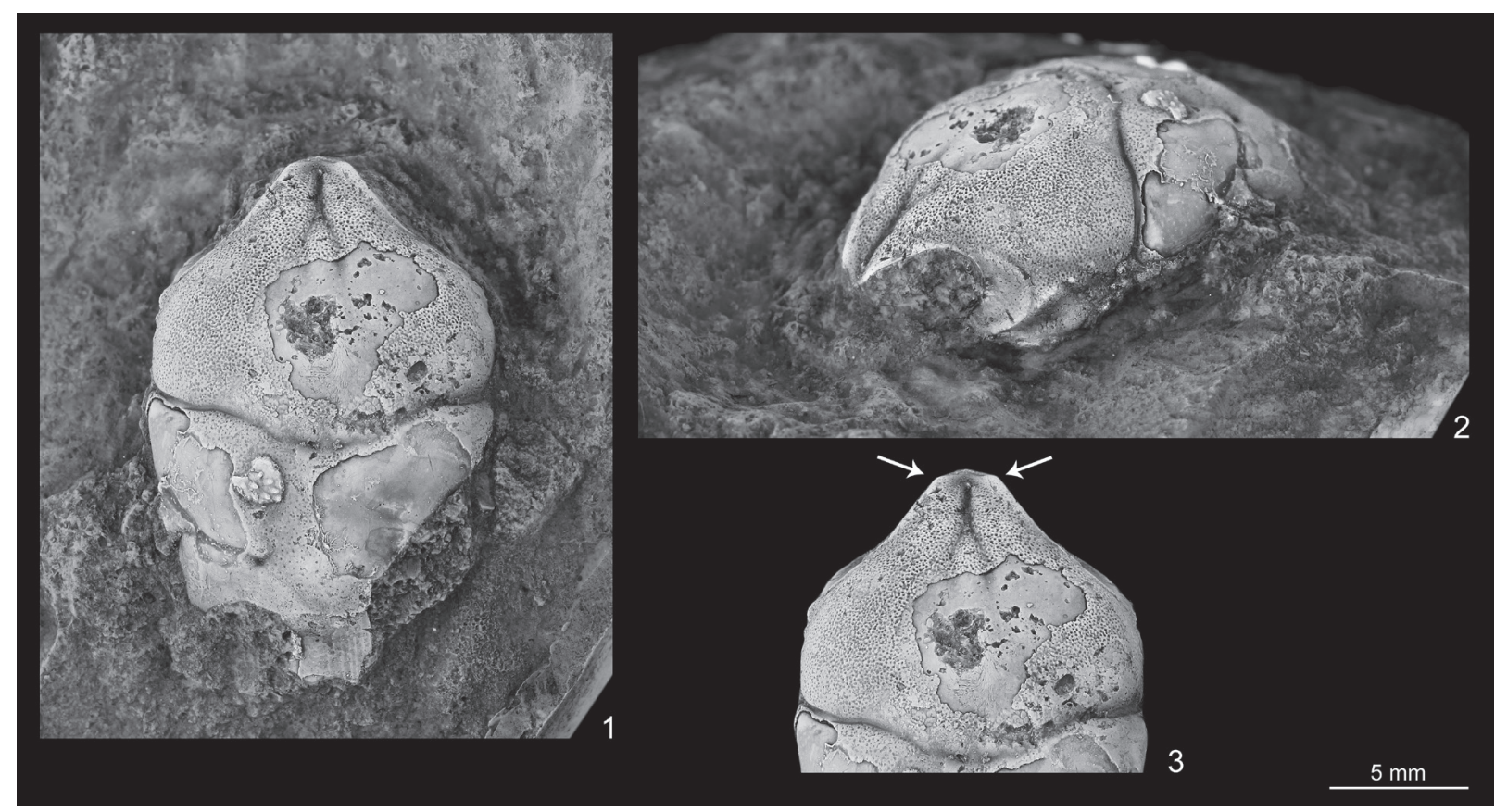

Fig. 2. Tanidromites raboeufi n. sp., MHNLM 2013.2.1, from the upper Bathonian of La Bigotière, near Crannes-en-Champagne, Sarthe, France. (A) Dorsal view; (B) Oblique orbital view; (C) Anterior carapace, showing orbitofrontal margin. Arrows = pseudorostral nodes. Photographs: Barry van Bakel. 
Tanidromites maerteni from the lower upper Bajocian of Maizet, Calvados, northwest France, is also known only from the holotype. It differs from $T$. $r a$ boeufi $\mathrm{n}$. sp. in having a flatter carapace, much stronger grooves around the mesogastric region, a shallower cervical groove, a clearly defined postcervical groove, an epibranchial lateral spine, and a shorter cardiac region. A hepatic pit is present on the right-hand side of the holotype of T. maerteni where cuticle is preserved; thus, this is an additional differentiating feature between these Bathonian and Bajocian species. The tumidity of the carapace may depend on the ontogeny of the crab (see Klompmaker et al., 2012, Klompmaker, 2013) however there is no significant size difference between the two species.

Tanidromites montreuilense from the lower Callovian of Montreuil-Bellay, Maine-et-Loire, northwest France, was described on the basis of three specimens. This species differs from $T$. raboeufi $\mathrm{n}$. sp. in having distinctly defined branchiocardiac, cardiac and postcervical grooves, a well-defined anterior groove, a shorter (in dorsal view) carapace proportion anterior of the cervical groove, stronger pseudorostral spines (Crônier and Boursicot, 2009; pl. 1, figs. 7, 8), and in granules of the anterolateral margin (Crônier and Boursicot, 2009; pl. 1, fig. 3). In addition, both the cuticle and the internal mould of T. montreuilense show a granular ornament, unlike the pits seen in T. raboeu$f i$ n. sp.; however, we must be cautious with a final observation since it is unsure which cuticular layer is preserved in the different specimens.

Several specimens have been described of Tanidromites richardsoni. The holotype, from the lower Bathonian at Wotton-under-Edge, southern Cotswolds, England, was refigured by Withers (1951; pl. 15, figs 1-3). This particular specimen has only a few fragments of cuticle preserved, and shows small, yet acute, outer orbital spines. Withers also described a second specimen from the same locality and level, but that one is rather worn at the margins. Donovan (1962) described, but did not illustrate, an additional specimen from Somerset, England; it is unclear from the description whether this specimen has cuticle preserved or not. Donovan (1962; p. 195) noted, “...behind the base of the broken-off antero-lateral spine, on the right side, is clearly visible the base of a second, smaller spine". More recently, Schweigert and Koppka (2011) described a single specimen, without rostrum, from the Sengenthal Formation of Göllersreuth, Franconia, Germany. This specimen is preserved with cuticle; it is stated by Schweigert and Koppka (2011; p. 5) that 'the anterolateral edge bears a prominent spine', and the dorsal surface is covered with pustules. The prominent outer orbital spine, the granular cuticle microstructure, the well-defined epigastric lobes, the weak anterior groove, and a rather wide anterior portion of the rostrum with convex margins (Withers 1951; pl. 15, fig. 1) differentiate $T$. richardsoni from $T$. raboeufi $\mathrm{n}$. sp.

Tanidromites lithuanicus from the middle Callovian, Papartine, Lithuania, is known from the holotype only, which is easily distinguished from $T$. raboeufi $\mathrm{n}$. sp. by its more distinctly defined carapace regions and well-defined cervical and branchiocardiac grooves.

Currently, Tanidromites pustulosa from the Tithonian of Štramberk, Moravia, Czech Republic, is known only from the type series (Schweitzer and Feldmann, 2010b; p. 58). The species is relatively short, with a proportionally short rostrum and a steep orbital margin, unlike features displayed by T. raboeufi n. sp. In addition, the epigastric lobes are clearly defined in $T$. pustulosa while they are very weak or obsolete in $T$. raboeufin. sp.

The type species, T. insigne, has distinct anterior grooves, well-defined epigastric lobes and mesogastric region, and a wider rostrum without pseudorostral nodes.

Tanidromites etalloni has long been considered a junior synonym of $T$. insigne, but re-evaluation of the holotype and additional material by Starzyk (2013) has recently proved the validity of this species; it is apparently confined to the Kimmeridgian of Poland. It is closely similar to $T$. insigne, and as such shares the same differences in comparison with T. raboeufi n. sp., but an additional differential feature is the shape of the outer orbital fossa. This area is rounded near the outer orbital corner in T. insigne and T. raboeufi $\mathrm{n}$. sp., while it is narrower, and subtriangular, in T. etalloni (compare Starzyk, 2013; figs. 4e, 5d).

Tanidromites scheffnerae was established on the basis of a single specimen from the upper Kimmeridgian of Gundelsheim, southern Germany; additional specimens from southern Poland, of middle and upper Oxfordian age, were described and figured by Starzyk (2013). Its carapace lacks a spine or tubercles at the outer orbital angle, has moderately developed epigastric lobes, but lacks pseudorostral nodes. These features differentiate it from $T$. raboeufi $\mathrm{n}$. sp. In addition, the carapace of $T$. scheffnerae is more convex in both directions, however, size difference and thus ontogenetic variation must be taken into account.

The type locality of T. sculpta is near Sigmaringen, southern Germany, where it was recovered from Kim- 

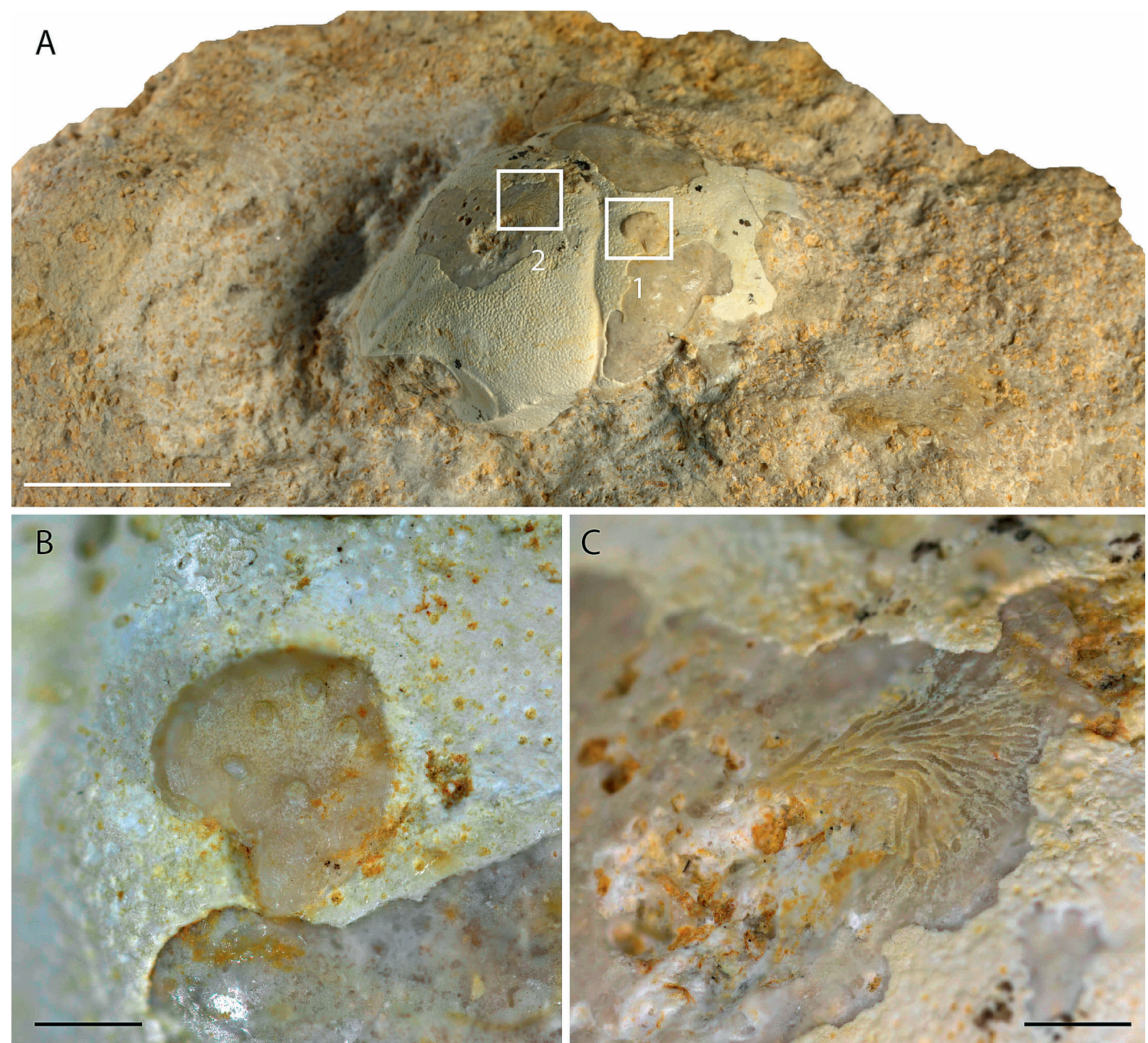

Fig. 3. Occurrence of epibionts on MHNLM 2013.2.1, holotype of Tanidromites raboeufin. sp. (A) General view; boxes: (1) Complete bryozoan colony settled on the outside of the carapace; (2) Underside view of the bryozoan colony settled on the inside of the carapace; (B) Close-up of complete colony on cuticle; (C) Close-up of basal imprint of a colony on carapace portion devoid of cuticle. Scale bars: $\mathrm{A}=10.0 \mathrm{~mm}, \mathrm{~B}-\mathrm{C}=500 \mu \mathrm{m}$. Photographs: Ninon Robin.

meridgian rocks (for details see Schweigert and Koppka, 2011; p. 9). It is known from diverse localities in Poland (Starzyk, 2013; p. 183) and southern Germany (Schweigert and Koppka, 2011). For a detailed discussion of its synonymy and type series, see Schweigert and Koppka (2011; p. 9). This species is flatter in transverse section in its complete size range. The outer orbital fossa of T. sculpta is similar to that of T. etalloni: narrowing, subtriangular, and lacking a distinct spine in the outer orbital corner. A specimen of T. sculpta with cuticle preserved shows an ornament of larger granules, which differs from the pitted cuticle of $T$. $r a$ boeufin. sp.

\section{Epibionts}

The holotype of Tanidromites raboeufin. sp. shows two epibionts on the upper and lower sides of the cuticle on the dorsal side of the crab (Fig. 3). We identify these epibionts as juvenile colonies of bryozoans (with circu- 


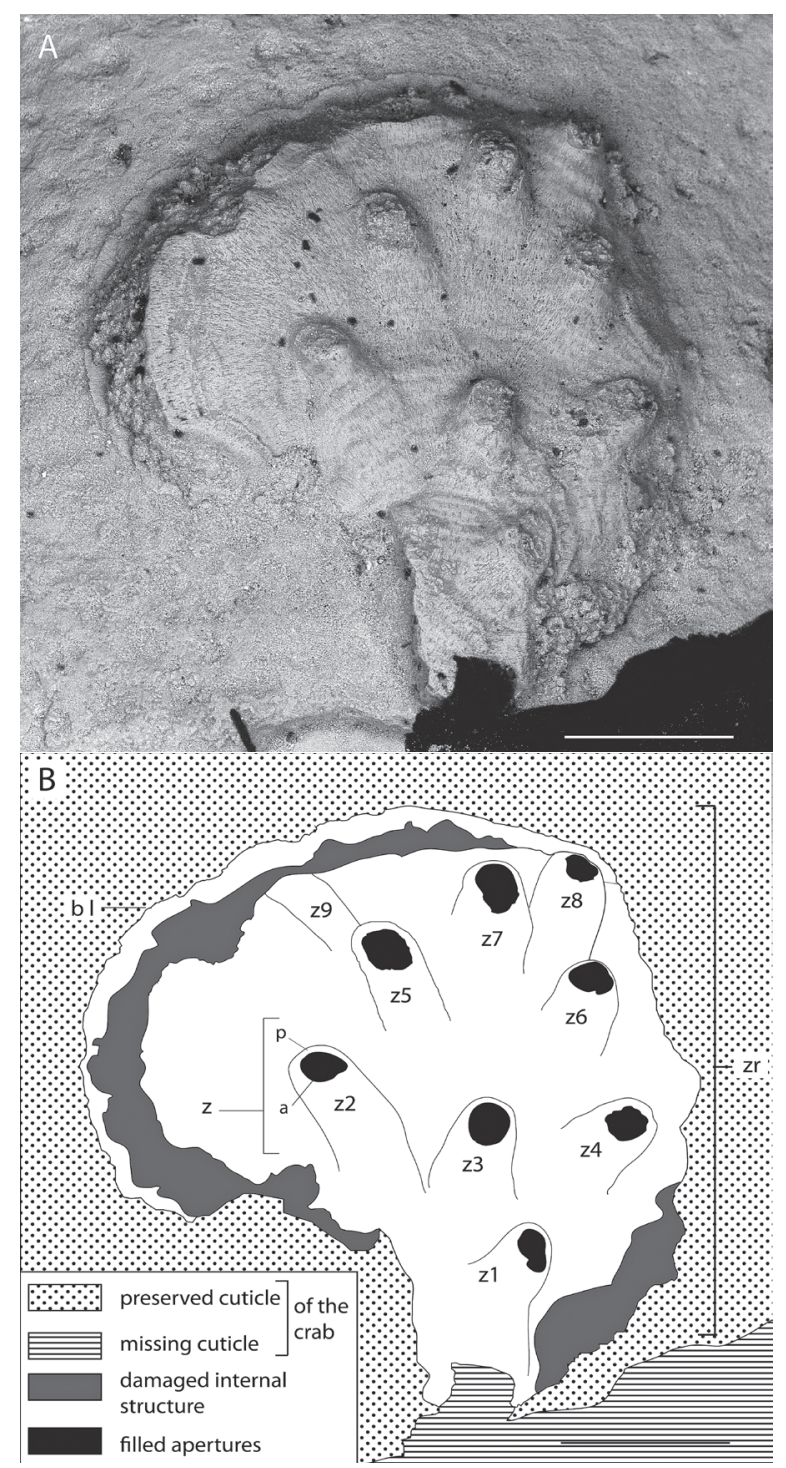

Fig. 4. Complete bryozoan colony. (A) SEM picture; (B) Interpretative line-drawing: $\mathrm{a}=$ aperture, $\mathrm{an}=$ possible ancestrula, $\mathrm{bl}$ $=$ presumed basal lamina, $\mathrm{p}=$ peristome, $\mathrm{z} 1-\mathrm{z} 9=$ visible $\mathrm{zoecia}$ $1-9, \mathrm{zr}=$ zoarium. Scale bars $=500 \mu \mathrm{m}$.

lar zooecial apertures; see Hayward and Ryland, 1985).

The first shows a clear three-dimensional structure and is settled directly on top of the preserved cuticle (Fig. 3A, B). On the second colony, all that can be seen are the basal outlines of the zooids as defined by the vertical interzooidal walls; the zooecial chambers are infilled by calcite cement, and the apertures are not visible (Fig. 3A, C). This second colony is settled where the cuticle is missing, broken during the fossil splitting. This kind of preservation correspond thus to the colony
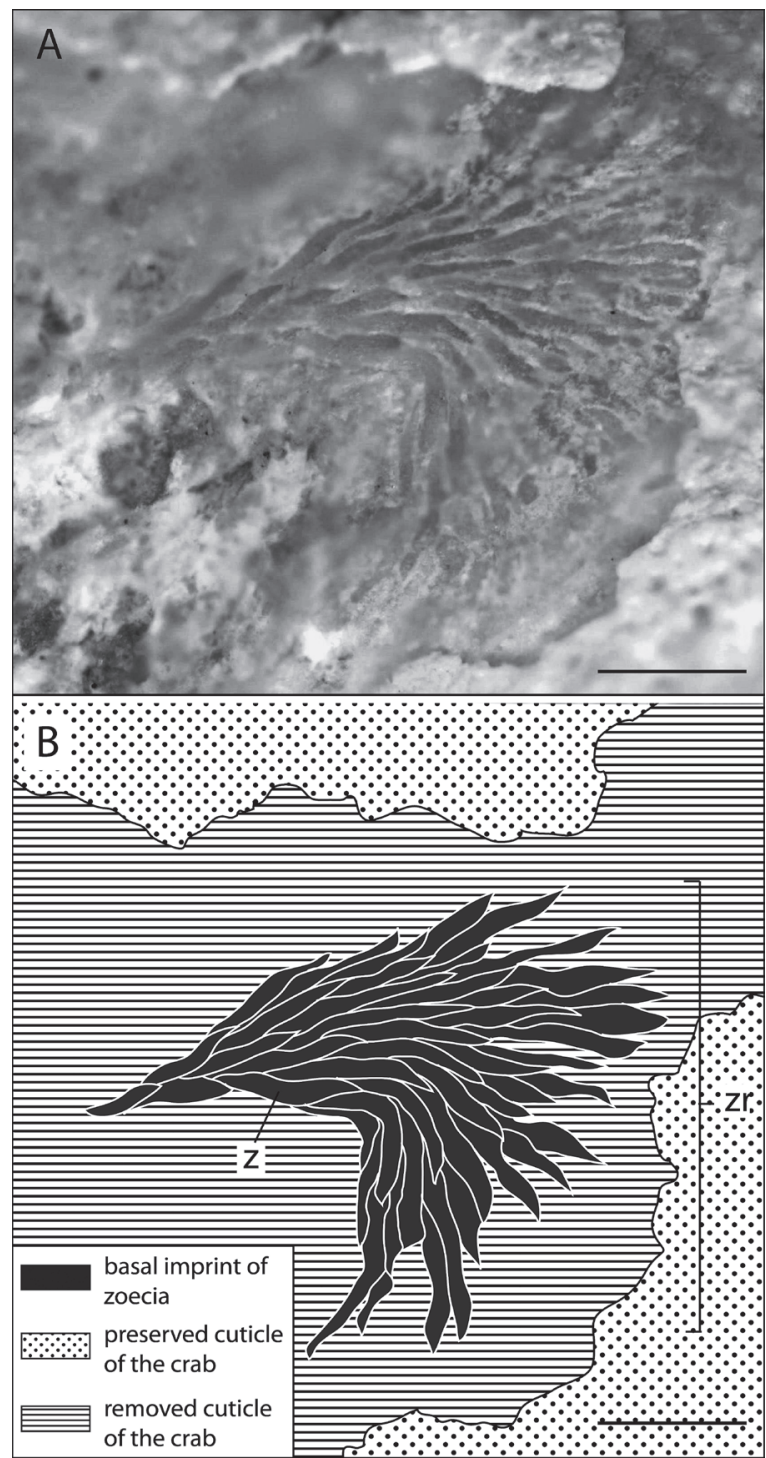

Fig. 5. Basal imprint of bryozoan colony. (A) Optical picture; (B) Interpretative drawing: $\mathrm{z}=$ apparent zoecium, $\mathrm{zr}=$ zoarium. Scale bars $=500 \mu \mathrm{m}$.

visible from the underside, necessarily settled on the inside of the crab carapace.

Phylum BRYOZOA Ehrenberg, 1831

Class STENOLAEMATA Borg, 1926

Order CYCLOSTOMATA Busk, 1852

Suborder TUBULIPORINA Milne Edwards, 1838

Family Incertae sedis Morphogenus Berenicea Lamouroux, 1821 


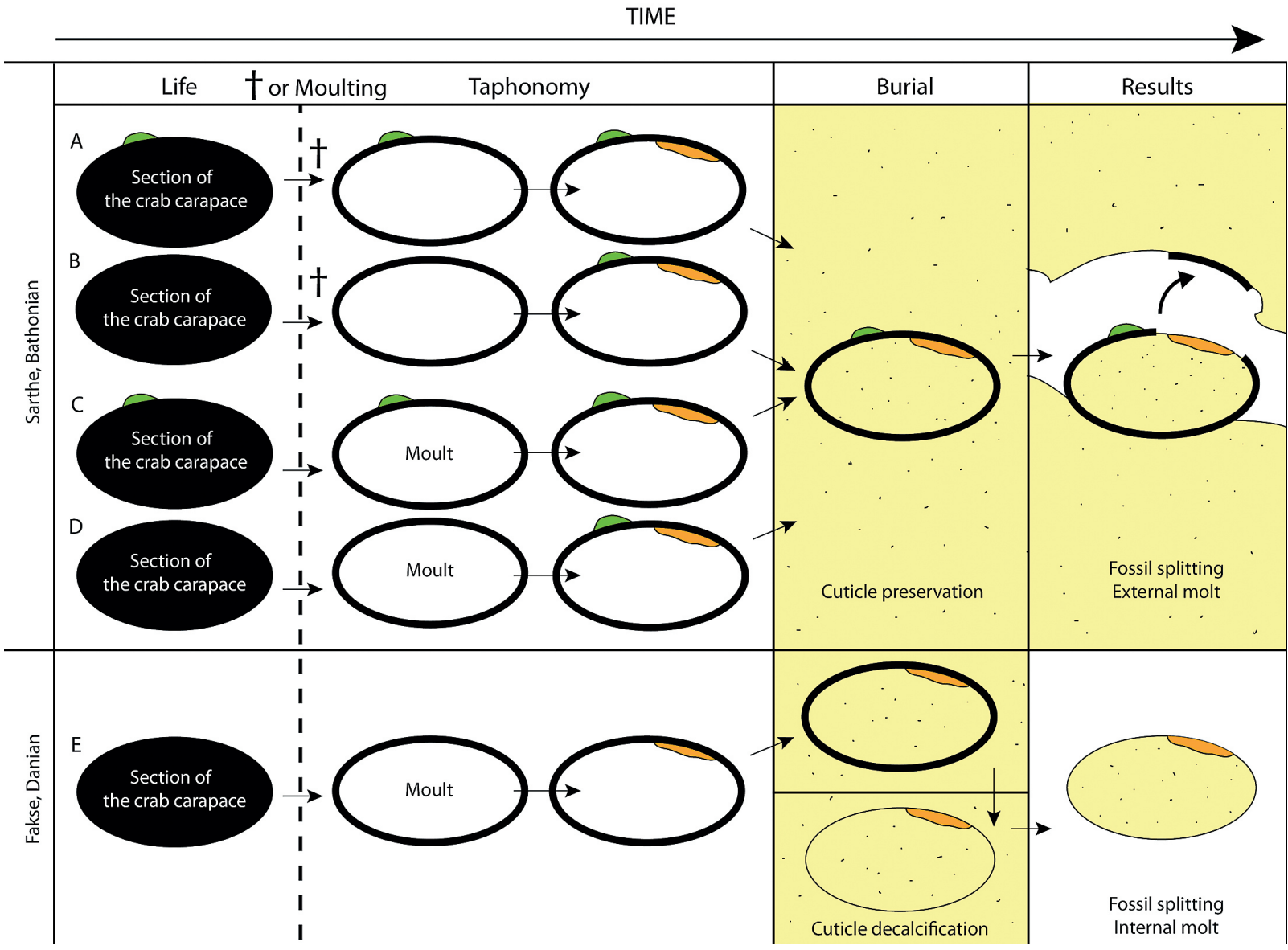

Fig. 6. Schematic representation of all the possible scenarii of association between the observed bryozoans and brachyurans. A, B, C, D. Possible scenarii for T. raboeufi nov. sp. from Sarthe, Late Bathonian, western France (MHNLM 2013.2.1.); E. Scenario for Dromiopsis rugosa (von Schlotheim, 1820) from Fakse, Middle Danian, eastern Denmark (MNHB-MB.A19171).

(Sensu Taylor and Sequeiros (1982): Undetermined bereniciform tubuloporinid)

Description of the complete colony on the outside of the carapace. Tiny spread-out colony (nine visible zooecia), $1.75 \mathrm{~mm}$ in length and $1.45 \mathrm{~mm}$ in width (Fig. 4A-B); encrusting zoarium apparently unilamellar. Zooecia almost parallel to zoarial surface, arranged in quincunx (Fig. 4A). Tubular, rather short zooecia with circular apertures. Apparent zoecia length 0.4-0.5 mm. Zoecia width rather constant at $0.23 \mathrm{~mm}$ (Fig. 3B). Peristomes mostly damaged but probably originally short (Fig. 4B). Approximate apertural diameter 0.11 $\mathrm{mm}$ (Fig. 4B). Wrinkled surface towards youngest zooecia (Fig. 3A). Basal lamina visible at periphery of colony (Fig. 4B). Gonozoid lacking.

Description of the colony on the inside of the cara- pace and visible from the underside. Colony of about 40 zooecia, $2.5 \mathrm{~mm}$ in length and $1.5 \mathrm{~mm}$ in width (Fig. $5 \mathrm{~A}, \mathrm{~B})$. Colony observable by the basal outlines of the zooids, as defined by the vertical interzooidal walls. Zoocial chambers infilled by calcite cement. Apertures not visible (Fig. 3A, C).

Identification. The complete specimen presents a ramose, encrusting and sheet-like zoarium; zooecia are tubular with circular apertures ascribable to Tubuliporina Milne Edwards, 1838. The colony is devoid of gonozooids. This lack impedes any familial determination for this colony of Jurassic cyclostomatous bryozoans. Such sheet-like tubuliporine may be informally assigned to the morphogenus Berenicea Lamouroux, 1821 as proposed by Taylor and Sequeiros (1982) which may correspond to the genera Rosacilla, Reptomultisparsa, Dacryopora, Microecia, Plagioecia, Diaper- 

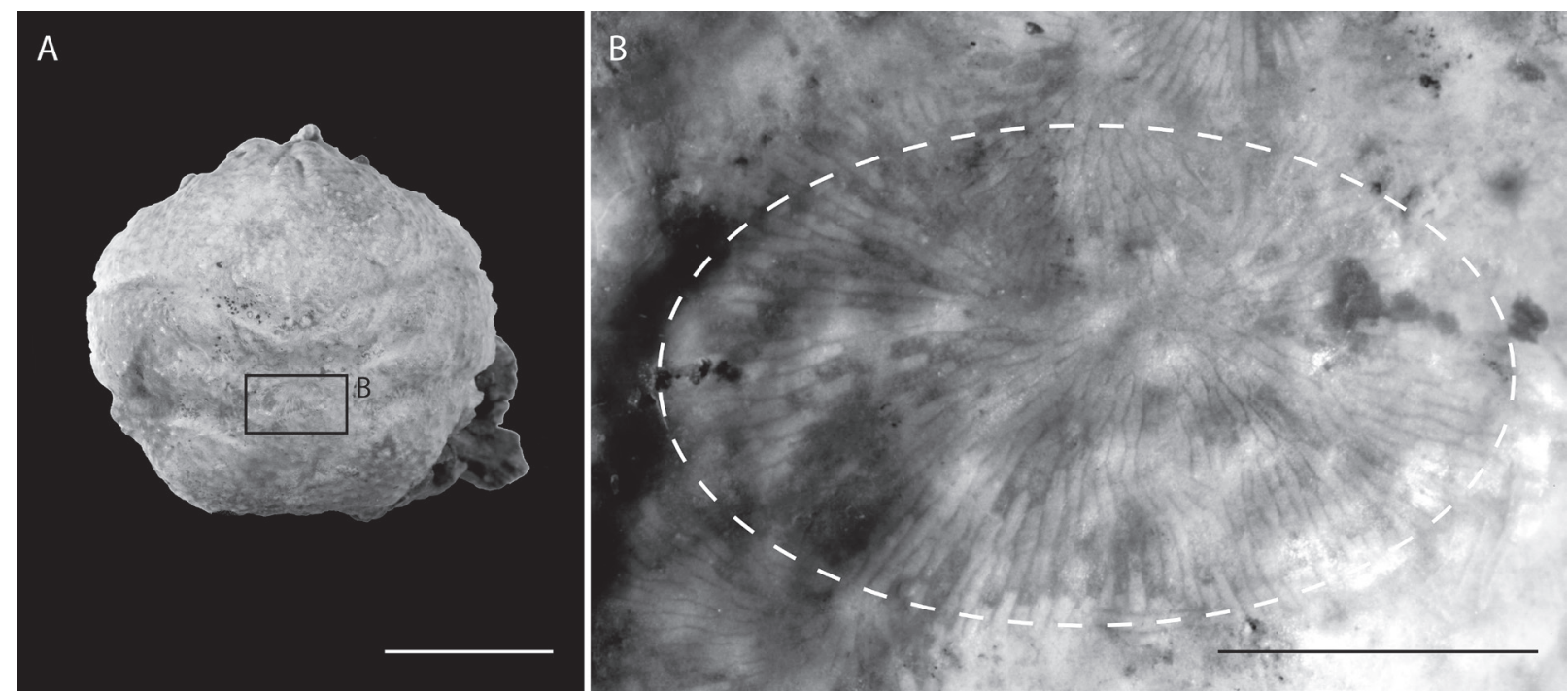

Fig. 7. Carapace of brachyuran crab from the Fakse quarry (Middle Danian, eastern Denmark) and underside view of the bryozoan zoarium similar to that seen on T. raboeufi n. sp. (compare Fig. 5). (A) Specimen MNHB-MB.A19171 of Dromiopsis rugosa; (B) Radial zoarium (delimited by dashed line) showing underside view of long and narrow zooecia. Scale bars: $\mathrm{A}=10.0 \mathrm{~mm}, \mathrm{~B}=2.0 \mathrm{~mm}$. Photographs: Ninon Robin.

oecia, Atractosoecia, Mesonopora or Hyporosopora, which distinguish on the basis of their gonozooid morphology. Although the volume of the colony visible from the underside is here not observable, the basal outlines of zooids evoke a ramose, encrusting and sheetlike zoarium allowing an assignation to the informal morphogenus Berenicea too.

\section{Discussion}

\section{Epibiosis, carapace resistance and environment}

The isolated carapace of T. raboeufi n. sp., devoid of appendages, may have either resulted from a moulting or from the decay of a dead organism (Fig 6A-D). The complete colony is clearly fixed on the outside of the carapace, on the preserved cuticle. This one may correspond equally to a post-mortem settlement or to a syn-vivo one (epizoozoans; Taylor and Wilson, 2003), in other words to a palaeosymbiosis between the crab and the bryozoans (Fig 6A-D; in green). Indeed, bryozoan colonies are well reported on extant alive brachyurans (Ryland and Stebbing, 1971; Mori and Manconi, 1990; Cadée, 1991; Becker and Wahl, 1996; Abello and Corbera, 1996; Parapar et al., 1997; Key et al., 1999; Gordon and Wear, 1999; Fernandez-Leborans, 2003; Waugh et al., 2004; McGaw, 2006; Savoie et al., 2007;
McDermott, 2007), sometimes even with true selection of the alive crab by the larva (J.-L. d'Hondt, pers. obs. on cheilostomes). The colony attached to the inside of the carapace and visible from the underside, necessarily settled on an exuvia, or post-mortem on the crab carapace. Indeed, if Stenolaemata bryozoans are reported as colonisers of extant brachyuran gills (for instance on Callinectes sapidus Rathbun, 1896; see Key et al., 1999), the present case differs strongly by its location in the metagastric region; which may only be permitted by a post-mortem settlement on the inside of the empty carapace (Fig 6A-D; in orange).

The settlement of bryozoan colonies on both inner and outer sides of crab carapaces has already been reported by Jakobsen and Feldmann (2004) in the decapod crustacean assemblage from the upper middle Danian of Fakse (eastern Denmark). The authors recorded and figured cheilostome and ctenostome bryozoans on exuviae of Dromiopsis rugosa (von Schlotheim, 1820), all devoid of cuticle. These bryozoans and other epibionts (e.g. clionid sponges, scleractinian corals, serpulid worms and brachiopods) have been interpreted postmortem. Some of these epibionts are attached to the outer side of the decalcified carapaces (see Jakobsen and Feldmann, 2004, fig. 7.3) but most of them - including bryozoan colonies - are attached to the carapace inner side (see Jakobsen and Feldmann, 2004; Figs. 6-11, 7.1-2). 
A newly examined specimen from Fakse (Fig. 7A) shows the radial outline of elongate cyclostomatous zoecia, perfectly flat and visible on the internal molt surface (decalcified cuticle; Fig. 7B). We interpret here this pattern as the underside view of a colony settled on the inside of the carapace (Fig. 6E) what Jakobsen and Feldmann (2004) did not explain. This pattern is thus, in all respect, similar to that observed on the holotype of T. raboeufi n. sp. from Sarthe, except in exhibiting no cuticle, completely decalcified during the burial (Fig. $6 \mathrm{E})$. In conclusion, this kind of colonial pattern -flat basal outlines of the zooids, below the cuticle-seems always to correspond to a post-mortem settlement on the inside of the carapace or of an exuvia. Thus, they necessarily have to be determinate as episkeletozoans (Taylor and Wilson, 2003), unlike the complete colony preserved on the cuticle outside for which nothing can be concluded.

Regarding the case of T. raboeufin. sp. (Sarthe), as the post-mortem colony (on the inside of the carapace) consists of up to 40 zooecia, the decapod carapace shall thus have stayed a certain time on the seafloor to be colonised on the inside by these colonies. Little is known about growth rates of modern cyclostomes, but it appears reasonable that such kind of colony forms in at least a couple of weeks (J.-L. d'Hondt., pers. obs.; P. Taylor, pers. comm.; see also Amui-Vedel et al., 2007 for cheilostomes). A rather 'long' period of settlement is also argued by the important calcification which permitted the colonies good preservation (as observed on the complete colony).

Carapaces of extant homolodromioids are known to be extremely fragile. This is illustrated by extant specimens damaged by simple handling for systematic issues (see Martin, 1991, figs. 4a, 5a; Cleva et al., 2007, figs 5.B, 6.A; Chan et al., 2009, fig. 93). However, our interpretation argues for a rather long exposure of the carapace, showing that the carapace of $T$. raboeufi $\mathrm{n}$. sp. certainly was not that weak and fragile. Feldmann and Gaździcki (1998) studied the cuticular ultrastructure of both fossil and extant homolodromiids, and demonstrated that the exocuticle of the extinct Antarctidromia inflata Förster, Gaździcki and Wrona, 1985 (Miocene of King George Island, Antarctica) was thicker than that of extant Homolodromia paradoxa A. Milne Edwards, 1880 offering a more rigid and resistant carapace than the fossil representatives. This may also be suggested for Jurassic tanidromitids, permitting external and internal fouling of their unburied carapaces by co-occurring bryozoans. This carapace resistance could simply be ascribed to local paleoenvironmental conditions (e.g., turbulent waves, particular temperatures).
Sheet-like tubuloporinid cyclostomes are broadly reported in the Middle and Late Bathonian of France (Normandy, Sarthe, Ardennes and Aisne) including in the Calcaire à Montlivaultia sarthacensis Formation (Guiller and Chelot, 1886). Such encrusting bereniciform colonies would have needed a proper indurated substrate on which to settle. In a calm environment with a carbonate muddy bottom, the isolated carapace (exuvia or carapace of a dead crab) may have appeared as a suitable substrate for these co-occurring larvae of $\mathrm{Be}$ renicea to settle and grow. However, we may suggest that at the first disturbance of the substrate, the carapace was buried by carbonate muds, the juvenile cyclostomes died and fossilisation started. This may explain the finding of solely small sized colonies on the present brachyuran substrate.

This observation confirm that, during the Bathonian, and particularly in muddy environments, encrusting cyclostomatous bryozoans needed to grow on alive or very steady substrates to succeed in growing to reach the colony mature stages. Such alive substrates may have been brachyurans (too poorly reported in the Late Bathonian of France), or even gastropod shell inhabited by paguroid crustaceans. Gastropod shells encrusted by mature colonies of the bereniciform Reptomultisparsa incrustans (d'Orbigny, 1850, and ICZN, 1986), indicating a paguroid dwelling, have rightly been reported in the Bathonian of Sarthe, only $15 \mathrm{~km}$ far from La Bigotière (Conlie; Buge and Fisher, 1970).

\section{Conclusion}

A new species of early crab, Tanidromites raboeufi nov. sp., is described from the upper Bathonian of Sarthe (France). The preservation of juvenile colonies of $\mathrm{Be}$ renicea (cyclostomatous bryozoans) on both outer and inner sides of its carapace (or exuvia) implies several possible scenarii of associations between these bryozoans and their substrate. The identification of a necessarily post-mortem colony composed of 40 zoecia indicates that the carapace of this fossil homolodromioid crab was not so weak and fragile than observed on its extant relatives. The present association is a snapshot of a post-mortem meeting (and possibly syn-vivo for one of the two colonies) between species cohabitating during the Bathonian. This supports that during Bathonian, and probably in particularly muddy environments, sheet-like tubulinoporines tried to colonise all available hard substrates and that only alive or very steady substrates permitted their growth to an adult stage. 


\section{Acknowledgements}

We are grateful to C. Schweitzer, A. Klompmaker and P. Taylor for reviewing our manuscript and for advising us on the accurate determination of the bryozoan colonies. We thank Nicolas Morel (curator, Musée Vert-Muséum d'Histoire naturelle du Mans) for the loan of the specimen and for discussion on its stratigraphical age. We are grateful to Patrick Raboeuf, who collected the specimen in September 2013 during rail construction works for the French high-speed train (TGV). We finally want to warmly thank John W.M. Jagt (Natuurhistorisch Museum Maastricht) for his contribution to the improvement of our manuscript and his thorough review of the English.

\section{References}

Abello P, Corbera J. 1996. Epibiont bryozoans (Bryozoa, Ctenostomatida) of the crab Goneplax rhomboides (Brachyura, Goneplacidae) off the Ebro delta (western Mediterranean). Miscellania Zoologica 19: 43-52.

Alcock A. 1900. Materials for a carcinological fauna of India. No. 6. The Brachyura Catometopa or Grapsoidea. Journal of the Asiatic Society of Bengal 69: 279-486.

Amui-Vedel AM, Hayward PJ, Porter JS. 2007. Zooid size and growth rate of the bryozoan Cryptosula pallasiana Moll in relation to temperature, in culture and in its natural environment. Journal of Experimental Marine Biology and Ecology 353: 1-12.

Bary A de. 1879. Die Erscheinung der Symbiose. Strassbourg, France: Trübner.

Becker K, Wahl M. 1996. Behaviour patterns as natural antifouling mechanisms of tropical marine crabs. Journal of Experimental Marine Biology and Ecology 203: 245-258.

Borg F. 1926. Studies on recent cyclostomatous Bryozoa. Zoologiska Bidrag fran Uppsala 10: 181-507.

Buge E, Lecointre G. 1962. Une association biologique (symbiose) entre un Bryozoaire et un Pagure dans le Quaternaire du Rio de Oro (Sahara espagnol). Bulletin de la Société géologique de France 4: 555-559.

Buge E, Fischer J-C. 1970. Atractosoecia incrustans (d'Orbigny) (Bryozoa Cyclostomata), espèce bathonienne symbiotique d'un pagure. Bulletin de la Société géologique de France 1: 126-133.

Busk G. 1852. An account of the Polyzoa and Sertularian zoophytes collected in the voyage of the "Rattlesnake" on the coasts of Australia and the Louisiade Archipelago. Pp. 343402 in: MacGilivray J, ed, Narrative of the voyage of "Rattlesnake". London, UK, T and W Boone Publishers.

Cadée GC. 1991. Carapaces of the shore crab Carcinus maenas as a substrate for encrusting organisms. Pp. 71-79 in: Bigey F., ed, Bryozoa: living and fossil. Nantes, France: Société des Sciences naturelles de l'Ouest de la France, Mémoire horssérie.

Chan TY, Ng PKL, Ahyong ST, Tan SH. 2009. Crustacean fauna of Taiwan: Brachyuran crabs, volume I. Carcinology in Taiwan and Dromiacea, Raninoida, Cyclodrippoida. Keelung, Taiwan: National Taiwan Ocean University.

Clément J-P, Chantraine J, Limasset J-C. 1987. Notice explicative, carte géologique de la France à 1/50 000, feuille Loué (357). Orléans, France: éditions du BRGM.
Cleva R, Guinot D, Albenga L. 2007. Annotated catalogue of brachyuran type specimens (Crustacea, Decapoda, Brachyura) deposited in the Muséum national d'Histoire naturelle, Paris. Part I. Podotremata. Zoosystema 29: 1-51.

Collins JSH, Wierzbowski A. 1985. Crabs from the Oxfordian sponge megafacies of Poland. Acta Geologica Polonica 35: 73-88.

Crônier C, Boursicot P-Y. 2009. A new decapod crustacean faunule from the Middle Jurassic of north-west France. Palaeontology 52: 1275-1289.

Donovan DT. 1962. New examples of the fossil crab Pithonoton from the Inferior Oolite of Gloucestershire and Somerset. Proceedings of the Geologists' Association 73: 193-196.

Ehrenberg, CG. 1831. Symbolae physicae seu icones et descriptiones animalium evertebratorum sepositis insectis quae ex itinere per Africam borealem et Asiam occidentalem Frederici Guilelmi Hemprich et Christiani Godofredi Ehrenberg studio redierunt.

Enay R, Cariou E, Bellion Y, Guiraud R, Mangold C, Thierry J. 1993. Callovian palaeoenvionments (162 to $158 \mathrm{Ma}$ ). Pp. 1516 in: Dercourt J, Ricou LE., Vrielynck B, eds, Atlas Tethys. Palaeoenvironments, Maps, Maps. Rueil-Malmaison, France: BEICIP-FRANLAB.

Feldmann RM. 2003. The Decapoda: new initiatives and novel approaches. Journal of Paleontology 77: 1021-1039.

Feldmann RM, Gaździcki A. 1998. Cuticular ultrastructure of fossil and living homolodromiid crabs (Decapoda: Brachyura). Acta Palaeontologica Polonica 43, 1-19.

Feldmann RM, Lazăr I, Schweitzer CE. 2006. New crabs (Decapoda: Brachyura: Prosopidae) from Jurassic (Oxfordian) sponge bioherms of Dobrogea, Romania. Bulletin of the Mizunami Fossil Museum 33: 1-20.

Fernandez-Leborans G. 2003. Protist-bryozoan-crustacean hyper epibiosis on Goneplax rhomboides (Linnaeus, 1758) (Decapoda, Brachyura) from the NW Mediterranean coast. Crustaceana 76: 479-497.

Förster R, 1986. Der erste Nachweis eines brachyuren Krebses aus dem Lias (oberes Pliensbach) Mitteleuropas. Mitteilungen aus der Bayerischen Staatssammlung für Paläontologie und historische Geologie 26: 25-31.

Förster R, Gaździcki A, Wrona R. 1985. First record of a homolodromiid crab from a lower Miocene glacio-marine sequence of West Antarctica. Neues Jahrbuch fur Geologie und Palaontologie, Monatshefte 1985: 340-348.

Fraaije RHB, Van Bakel BWM, Guinot D, Jagt JWM. 2013. A new Middle Jurassic (Bajocian) homolodromioid crab from northwest France; the earliest record of the Tanidromitidae. Boletín de la Sociedad Geológica Mexicana 65: 249-254.

Glaessner MF. 1929. Crustacea Decapoda. Pars 41 in: Pompeckj JF, ed, Fossilium Catalogus I: Animalia Pt. 41. Berlin, Germany: W. Junk.

Gordon DP, Wear RG. 1999. A new ctenostome bryozoan ectosymbiotic with terminal-moult paddle crabs (Portunidae) in New Zealand. New Zealand Journal of Zoology 26: 373-380.

Guillier A, Chelot E. 1886. Géologie du département de la Sarthe. Le Mans, Paris, France: E. Monnoyer and Comptoir géologique de Paris.

Guinot D. 1977. Propositions pour une nouvelle classification des Crustacés Décapodes Brachyoures. Comptes Rendus hebdomadaires des Séances de l'Académie des Sciences, série D 285: 1049-1052. 
Guinot D, Tavares M, Castro P. 2013. Significance of the sexual openings and supplementary structures on the phylogeny of brachyuran crabs (Crustacea, Decapoda, Brachyura), with new nomina for higher-ranked podotreme taxa. Zootaxa 3665: 1-414.

Gutt J, Shickan T. 1998. Epibiotic relationships in the Antarctic benthos. Antarctic Science 10: 398-404.

Haug J, Haug C. 2014. Eoprosopon klugi - the oldest unequivocal and most "primitive" crab reconsidered. Palaeodiversity 7: $149-158$

Hayward PJ, Ryland JS. 1985. Cyclostome bryozoans: keys and notes for the identification of the species. Synposes of the British Fauna. Leiden: Brill.

Hyžný M, Schlögl J, Krobicki M. 2011. Tanidromites insignis (von Meyer, 1857) (Crustacea: Decapoda: Brachyura) from Late Jurassic non-biohermal facies of the Western Tethys (Pieniny Klippen Belt, Western Carpathians, Slovakia. Neues Jahrbuch für Geologie und Paläontologie Abhandlungen 262: 213-226. doi: 10.1127/0077-7749/2011/0193

ICZN 1986. Opinion 1392, Reptomultisparsa d'Orbigny, 1853 (Bryozoa, Cyclostomata): type species designated. Bulletin of Zoological Nomenclature 43: 140-141.

Jakobsen SL, Feldmann RM. 2004. Epibionts on Dromiopsis rugosa (Decapoda: Brachyura) from the late Middle Danian limestones at Fakse Quarry, Denmark: novel preparation techniques yield amazing results. Journal of Paleontology 78: 953-960.

Key Jr MM, Winston JE, Volpe JW, Jeffries WB, Voris HK 1999. Bryozoan fouling of the blue crab Callinectes sapidus at Beaufort, North Carolina. Bulletin of Marine Science 64: 513-533.

Klicpera A, Taylor PD, Wesphal H. 2013. Bryoliths constructed by bryozoans in symbiotic associations with hermit crabs in a tropical heterozoan carbonate system, Golfe d'Arguin, Mauritania. Marine Biodiversity 43: 429-444. doi: 10.1007/ s12526-013-0173-4

Klompmaker AA. 2013. Extreme diversity of decapod crustaceans from the mid-Cretaceous (late Albian) of Spain: implications for Cretaceous decapod paleoecology. Cretaceous Research 41: 150-185.

Klompmaker AA, Feldmann RM, Schweitzer CE. 2012. A hotspot for Cretaceous goniodromitids (Decapoda: Brachyura) from reef associated strata in Spain. Journal of Crustacean Biology 32: 780-801.

Klompmaker AA, Hyžný M., Jakobsen SL. 2015. Taphonomy of decapod crustacean cuticle and its effect on the appearance as exemplified by new and known taxa from the Cretaceous-Danian crab Caloxanthus. Cretaceous Research 55: 141-151.

Lamouroux J. 1821. Exposition méthodique des genres de l'ordre des polypiers. i-viii. Paris: Agasse.

Latreille PA. 1802. Histoire naturelle, générale et particulière des Crustacés et des Insectes, ouvrage faisant suite à l'Histoire naturelle générale et particulière, composée par Leclerc de Buffon, et rédigée par C.S. Sonnini, membre de plusieurs sociétés savantes. Tome 3. Paris: F. Dufart.

Martin JW. 1991. Crabs of the family Homolodromiidae, III. First record of the larvae. Journal of Crustacean Biology 11: 156-161.

McDermott JJ. 2001. Symbionts of the hermit crab Pagurus longicarpus Say, 1817 (Decapoda: Anomura): new observa- tions from New Jersey waters and a review of all known relationships. Proceedings of the Biological Society of Washington 114: 624-639.

McDermott JJ. 2007. Ectosymbionts of the non-indigenous Asian shore crab, Hemigrapsus sanguineus (Decapoda: Varunidae), in the western north Atlantic, and a search for its parasites. Journal of Natural History 41: 2379-2396.

McGaw IJ. 2006. Epibionts of sympatric species of Cancer crabs in Barkley Sound, British Columbia. Journal of Crustacean Biology 26: 85-93.

Mégnien C. 1980. Synthèse géologique du bassin de Paris. Orléans, France: Editions du BRGM.

Meyer H von. 1857. Mittheilungen, an Prof. Bronn gerichtet. Neues Jahrbuch für Mineralogie, Geognosie, Geologie und Petrefaktenkunde 1857: 556.

Meyer H von. 1858. Mittheilungen an Prof. Bronn gerichtet. Neues Jahrbuch für Mineralogie, Geognosie, Geologie und Petrefaktenkunde 1858: 61.

Meyer H von. 1860. Die Prosoponiden oder die Familie der Maskenkrebse. Palaeontographica 7: 183-222.

Milne Edwards A. 1838. Mémoire sur les Crisies, les Hornères et plusieurs autres Polypes. Annales des Sciences Naturelles 9: 193-238.

Milne Edwards A. 1880. Reports on the results of dredging under the supervision of Alexander Agassiz in the Gulf of Mexico and in the Carribean Sea, 1877-79, by the U.S. Coast Survey Steamer "Blake" VIII. Etudes sur les Crustacés, 1ère Partie. Bulletin of the Museum of Comparative Zoology 8: 1-68.

Mori M, Manconi R. 1990. Macroepizoites associated with Paromola cuvieri (Risso, 1816) (Decapoda, Homolidae) of the Ligurian Sea. Crustaceana 58: 124-129.

Orbigny A d'. 1850. Prodrome de Paléontologie stratigraphique universelle des animaux mollusques et rayonnés. Volume 1. Paris: Masson.

Parapar J, Fernandez L, Gonzalez-Gurriaran E, Muino R. 1997. Epibiosis and masking material in the spider crab Maja squinado (Decapoda: Majidae) in the Ria de Arousa (Galicia, NW Spain). Cahiers de Biologie marine 38: 221-234.

Quenstedt FA. 1856-1857. Der Jura. Tübingen: Laupp.

Rathbun MJ. 1896. The genus Callinectes. Proceedings of the United States National Museum 18: 349-375.

Ryland JS, Stebbing ARD. 1971. Settlement and orientated growth in epiphytic and epizoic bryozoans. Pp. 105-123 in: Crisp DJ, ed, Fourth European Marine Biology Symposium. London, UK: Cambridge University Press.

Savoie L, Miron G, Biron M. 2007. Fouling community of the snow crab Chionoecetes opilio in Atlantic Canada. Journal of Crustacean Biology 27: 30-36.

Schembri PJ. 1982. Feeding behaviour of fifteen species of hermit crabs (Crustacea: Decapoda: Anomura) from the Otago region, southeastern New Zealand. Journal of Natural History 16: 859-878.

Schlotheim EF von. 1820. Die Petrefaktenkunde auf ihrem jetzigen Standpunkte durch die Beschreibung seiner Sammlung versteinerter und fossiler Überreste des Thier- und Planzenreichs erläutert. Gotha: Beckersche Buchhandlung.

Schweigert G, Koppka J. 2011. Decapods (Crustacea: Brachyura) from the Jurassic of Germany and Lithuania, with descriptions of new species of Planoprosopon and Tanidromites. Neues Jahrbuch für Geologie und Paläontologie Abhandlungen 260: 221-235. 
Schweitzer CE, Feldmann RM. 2008. A new classification for some Jurassic Brachyura (Crustacea: Decapoda: Brachyura: Homolodromioidea): families Goniodromitidae Beurlen, 1932 and Tanidromitidae, new family. Senckenbergiana lethaea 87: 119-156.

Schweitzer CE, Feldmann RM. 2009. Revision of the Genus Cyclothyreus Remeš, 1895 (Decapoda: Brachyura: Dromioidea). Neues Jahrbuch für Geologie und PaläontologieAbhandlungen 253: 357-372.

Schweitzer CE, Feldmann, RM. 2010a. The oldest Brachyura (Decapoda: Homolodromioidea: Glaessneropsoidea) known to date (Jurassic). Journal of Crustacean Biology 30: 251-256.

Schweitzer CE, Feldmann RM. 2010b. The genus Coelopus Étallon, 1861 (Brachyura: Glaessneropsoidea: Longodromitidae) with new species. Neues Jahrbuch für Geologie und Paläontologie Abhandlungen 258: 51-60.

Starzyk N. 2013. Jurassic crabs: new characters of carapace diagnostic to known tanidromitid species. Neues Jahrbuch für Geologie und Paläontologie Abhandlungen 269: 173-187.

Taylor PD. 1994. Evolutionary palaeoecology of symbioses between bryozoans and hermit crabs. Historical Biology 9: 157-205.

Taylor PD, Sequeiros L. 1982. Toarcian bryozoans from Belchite in north-east Spain. Bulletin of the British Museum (Natural History).Geology 36: 117-129.

Taylor PD, Wilson MA. 2002. A new terminology for marine organisms inhabiting hard substrates. Palaios 17: 522-525.

Taylor PD. 2009. Bryozoans from the Middle Jurassic of Balin, Poland: a revision of material described by AE. Reuss (1867). Annalen des Naturhistorischen Museums in Wien, Serie A 110: $17-54$.

Taylor PD, Schembri PJ, Cook PL. 1989. Symbiotic associations between hermit crabs and bryozoans from the Otago region, southeastern New Zealand. Journal of Natural History 23: 1059-1085.

Wahl M. 1989. Marine epibiosis. I. Fouling and antifouling: some basic aspects. Marine Ecology Progress Series 58: 75-189.

Walker SE. 1988. Taphonomic significance of hermit crabs (Anomura: Paguridea): Epifaunal hermit crab-infaunal gastropod example. Palaeogeography, Palaeoclimatology, Palaeoecology 63: 45-71.

Walker SE, Miller W III. 1992. Organism-substrate relations: toward a logical terminology. Palaios 7: 236-238.

Waugh DA, Feldmann RM, Crawford RS, Jakobsen SL, Thomas KB. 2004. Epibiont preservational and observational bias in fossil marine decapods. Journal of Paleontology 78: 961972.

Waugh DA, Feldmann RM, Schweitzer CE. 2009. Systematic evaluation of raninid cuticle microstructure. Bulletin of the Mizunami Fossil Museum 35: 15-41.

West RR. 1977. Organism-substrate relations: terminology for ecology and palaeoecology. Lethaia 10: 71-82.

Withers TH. 1951. Some Jurassic and Cretaceous crabs (Prosoponidae). Bulletin of the British Museum (Natural History), Geology Series 1: 171-186.

Woodward H. 1907. On a new brachyurous Crustacean from the "Clypeus-Grit" (Inferior Oolite) of the Cotteswold Hills. Geological Magazine 4: 79-81.

Zaton M, Taylor PD. 2009. Middle Jurassic cyclostome bryozoans from the Polish Jura. Acta Palaeontologica Polonica 54: 267-288.

Received: 14 October 2014

Revised and accepted: 10 February 2015

Published online: 17 August 2015

Editor: R. Vonk 